Greg Planchuelo, Moritz von der Lippe, Ingo Kowarik

\title{
Untangling the role of urban ecosystems as habitats for endangered plant species
}

Journal article | Accepted manuscript (Postprint)

This version is available at https://doi.org/10.14279/depositonce-9177

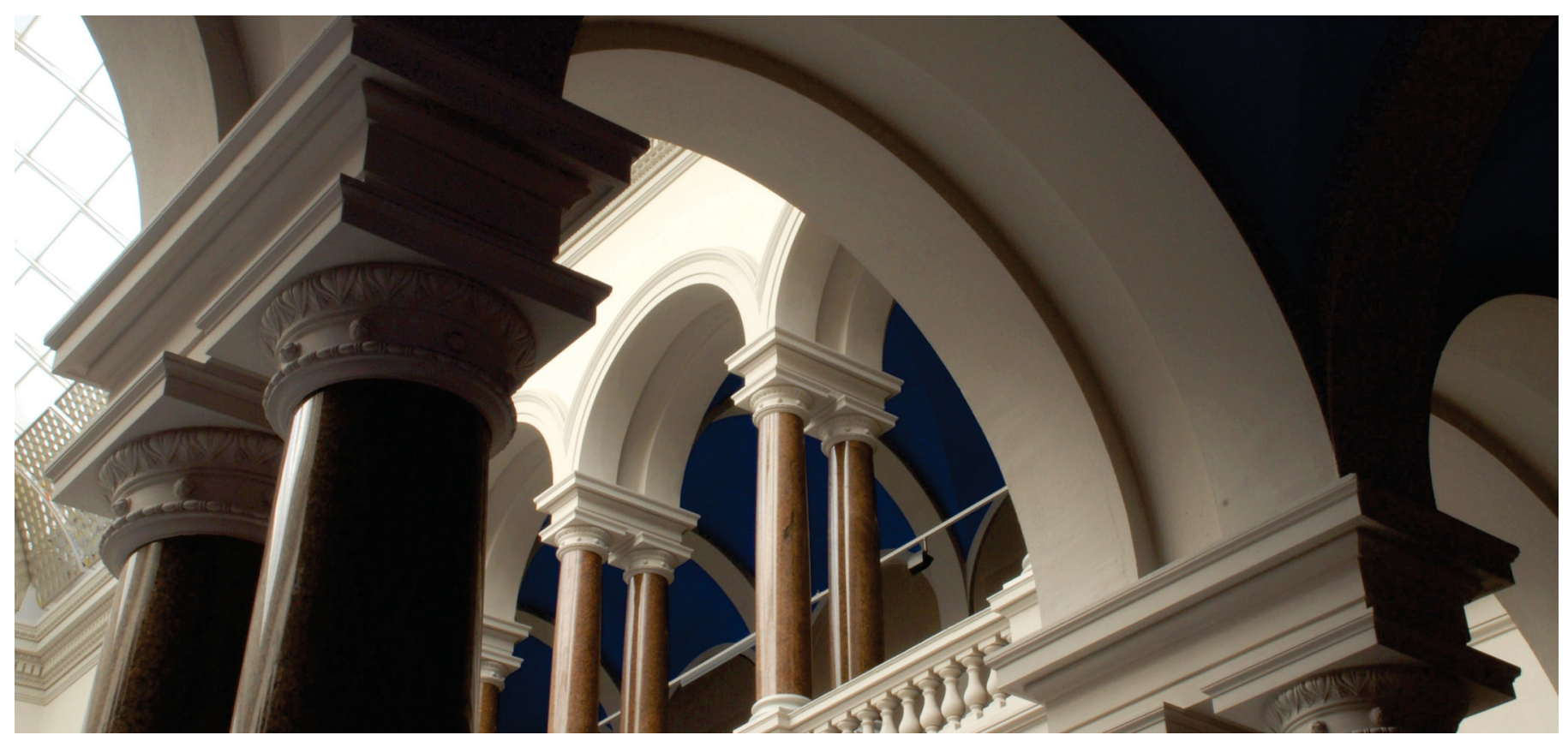

Planchuelo, G., von Der Lippe, M., \& Kowarik, I. (2019). Untangling the role of urban ecosystems as habitats for endangered plant species. Landscape and Urban Planning, 189, 320-334.

https://doi.org/10.1016/j.landurbplan.2019.05.007 


\section{Untangling the role of urban ecosystems as habitats for}

\section{endangered plant species}

\section{GREG PLANCHUELO ${ }^{1,3}$, MORITZ VON DER LIPPE ${ }^{1,2}$ AND INGO KOWARIK ${ }^{1,2}$}

${ }^{1}$ Department of Ecology, Ecosystem Science/Plant Ecology, Technische Universität Berlin, Rothenburgstr. 12, 12165 Berlin, Germany; E-mails: gregplanchuelo@mailbox.tu-berlin.de, kowarik@tu-berlin.de,moritz.vdlippe@tu-berlin.de

${ }^{2}$ Berlin-Brandenburg Institute of Advanced Biodiversity Research (BBIB), 14195 Berlin, Germany

${ }^{3}$ Corresponding author: Greg Planchuelo, E-mail: gregplanchuelo@mailbox.tu-berlin.de, Tel. +4930314 71282, Fax. +493031471355

Keywords: biodiversity conservation; ecological novelty; endangered species; population scale; remnant ecosystems; urban ecosystems.

\section{Highlights:}

- All populations of 213 endangered plants related to different ecosystems in Berlin

- Most populations were found in forests, grasslands and ruderal sites

- Novel urban ecosystems harbored most populations of endangered plants

- Yet population density was highest in natural remnants

- Strong arguments for broad approaches in urban biodiversity conservation 
Abstract: As urbanization accelerates globally, a better understanding of how cities contribute to biodiversity conservation is increasingly pressing. Previous studies reveal that cities can harbor a considerable biological richness, including endangered plant species. Yet, a key question on the urban contribution to plant conservation remains critically open, as little information is available on how populations of endangered plant species occur across different biotope types within cities and to what extent anthropogenically shaped vs. natural ecosystems provide habitats for endangered plants. We analyzed a unique dataset on the exact geographical position of 1,742 populations of 213 highly endangered plant species in Berlin. We first assessed the relative importance of Berlin's 12 major biotope classes as habitats of endangered plant species. Second, we applied the novel ecosystem concept to quantify endangered plant populations for natural remnants vs. hybrid vs. novel ecosystems within Berlin. Populations of endangered plant species were generally, although unevenly, associated with specific biotope classes, with forest, grassland, and ruderal biotopes as the most important habitats. Surprisingly, novel ecosystems harbored the highest numbers of total populations, of total species, and of species that were exclusively confined to one type of ecosystem novelty. Quantifying the relative importance of biotope classes and novel vs. (near-)natural ecosystems as habitats of endangered species demonstrates that the urban contribution to biodiversity conservation is best ensured by providing a range of ecosystems. Rather than prioritizing only natural remnants, we thus argue for broad approaches to urban biodiversity conservation that include novel ecosystems. 


\section{Introduction}

The potential contribution of cities to biodiversity conservation is becoming increasingly important in the Anthropocene period, in which urbanization and biodiversity loss are coinciding and accelerating global trends (Ellis 2015). While urban growth can threaten biodiversity outside cities (Mcdonald et al. 2008; Guneralp \& Seto 2013), urban regions have been reported to harbor high numbers of species (Kuhn et al. 2004; McKinney 2008) including rare and endangered species (Schwartz et al. 2002; Lawson et al. 2008; Lenzen et al. 2009; Shwartz et al. 2014; Ives et al. 2016). Of Australia's threatened species, for example, $30 \%$ occur in cities, and some are exclusively found in them (Ives et al. 2016). In consequence, conservation policies have increasingly come to urban areas in recent years, with claims that all urban ecosystems offer habitat functions for native species (Goddard et al. 2010; Kowarik 2011; Lepczyk et al. 2017; Nilon et al. 2017).

Yet, in their meta-analysis on urban biodiversity conservation, Shwartz et al. (2014) highlight gaps in knowledge that are vital for confirming the role of cities for biodiversity conservation. One major point is that studies of endangered species in urban regions largely do not account for the conspicuous heterogeneity in time and space that exists among urban ecosystems (Ramalho \& Hobbs 2012). Indeed, varying human impacts and a range of environmental barriers filter the composition of urban species assemblages (Williams et al. 2009; Aronson et al. 2016; Knapp et al. 2017; Kowarik \& von der Lippe 2018), since species are differently pre-adapted or able to adapt to urban conditions (McDonnell \& Hahs 2015). In consequence, species loss is seen in urban regions as well (Hahs et al. 2009). While the "human threat hypothesis" posits a negative relationship between increasing human dominance and the persistence of species (Lawson et al. 2008), a comparison of endangered 
species occurring in differently urbanized regions of California found no evidence for negative urbanization effects (Lawson et al. 2008). However, this may be due to the scale of the study, which did not allow for the habitat functions of natural remnants to be untangled from other, anthropogenically shaped urban biotopes.

In contrast to the general relevance of urban regions for biodiversity conservation, the relative importance of different ecosystem types within cities for endangered plant species has been much less studied. While natural remnants and conservation areas are the traditional conservation focus in cities (e.g. Godefroid \& Koedam 2003; Knapp et al. 2008; Diamond and Heinen 2016; Kendal et al. 2017; Zeeman \& Morgan 2018), a key question remains as to how novel urban ecosystems should be addressed from a conservation perspective (Kowarik 2011; Hobbs et al. 2014). Novel ecosystems, which are characterized by profound and likely irreversible changes to ecosystem features and/or species assemblages (Hobbs et al. 2009; Hobbs et al. 2013), are important components of urban regions (Kowarik 2011) and have been shown to harbor rare species (Goddard et al. 2010; Bonthoux et al. 2014; Kowarik \& von der Lippe 2018; Maclagan et al. 2018). To date, however, the extent to which urban ecosystems that differ in ecological novelty (i.e., along the spectrum from natural remnants to novel ecosystems; Hobbs et al. 2013) function as habitats of large sets of endangered plant species has not been quantified in comparative studies.

A recent pioneer study from Berlin made a first step by assessing the role of natural remnant, hybrid, and novel ecosystems as habitats for different groups of plant species (alien, native, endangered), based on expert assessments of the general occurrence and population establishment of species in each ecosystem category (Kowarik \& von der Lippe 2018). Our present study makes further steps forward towards understanding the role of different 
ecosystem types for endangered plant species in cities: first, by focusing on 1,742 spatially referenced populations of 213 endangered plant species that are priority species for biodiversity conservation in Berlin; second, by relating the exact location of these populations to biotope types that reflect the variety of ecological conditions and land uses in the metropolitan area of Berlin; and, third, by assigning each biotope type to one of the major novelty categories (i.e., natural remnant, hybrid, novel ecosystems).

This approach allowed us to quantify the relationships between populations of high priority conservation species and urban environments with regard to the biotope dimension and the dimension of ecological novelty. In detail, we addressed the following research questions: What is the relative contribution of (1) different biotope classes and (2) of natural remnant vs hybrid vs novel ecosystems within the metropolitan region of Berlin in harboring populations of endangered plant species? (3) To what extent do ecosystems that differ in ecological novelty share or exclusively host populations of endangered plant species? 


\section{Methods}

\subsection{Study area and study system}

The study was conducted in Berlin, Germany's capital and largest city, with 3.6 million inhabitants in 2017 and a total area of $891 \mathrm{~km}^{2}$. About $54 \%$ of Berlin's surface is covered by built-up areas and streets; green and blue spaces total $41 \%$ of the area, including forests (17.5\%), lakes and rivers (6\%), parks and other greenspaces (SenStadtUm 2016). The climate is temperate, with forests and wetlands as natural ecosystems. The city encompasses remnants of natural and agrarian landscapes, urban greenspaces with different land-use histories, and a range of novel ecosystems on vacant urban land and within the built-up areas (Sukopp 1990).

Berlin's flora has been well studied since the $18^{\text {th }}$ century (Sukopp 1987). Starting in the 1970s, information about species extinctions and declines within the area of today's Berlin has been synthesized and updated several times in Red Lists of endangered species (Seitz et al. 2018). Berlin's flora comprises 1,527 previously present taxa, but $46 \%$ of it has gone extinct or is currently being endangered in Berlin, referring to the well-known flora of the mid- $19^{\text {th }}$ century as a baseline (Seitz et al. 2018). Berlin's nature conservation authorities have identified 230 species with highest conservation priority as target species of Berlin's Flora Protection Program (Berliner Florenschutzkonzept); populations of these species are being monitored by Stiftung Naturschutz Berlin (2015). In this study, we used data about the spatial location of populations of 213 of these endangered priority species, including a total of 1,742 populations. The species have been assigned to different Red List categories (Seitz 
et al. 2018) and include 183 species that are threatened with extinction in Berlin, or believed to be locally extinct, and 19 highly endangered species; see Appendix A for details.

\subsection{Methodological approach}

We first linked the geographical position of each of the populations of the endangered plant species to the biotope it is located in to unravel the relative importance of different biotopes as habitats of endangered plant species (biotope scale). We then assigned all biotopes to a level of ecological novelty according to the novel ecosystem concept (Hobbs et al. 2013) to elucidate the relative importance of natural remnant vs hybrid vs novel ecosystems for the populations of the target species (novelty scale) (see Appendix B)

\subsection{Biotope types}

In the 1980s, a methodological approach was developed to assign the entire area of Berlin to biotope types that integrate various combinations of environmental conditions and land uses (Sukopp \& Weiler 1988). Today, the Berlin Environmental Atlas provides a comprehensive biotope map (SenStadtUm 2014) that divides Berlin into twelve major biotope classes: forests, grasslands, ruderal sites, standing bodies of water, built-up areas, bogs and marshes, hedges, green spaces, fields, moving bodies of water, heaths, and other types. These are further divided in biotope types, at several hierarchical levels, summing up to 7,483 subtypes. In the mapping dataset of the Berlin Environmental Atlas, Berlin is differentiated into 79,268 patches, and each of these patches is assigned to one of the 7,483 possible biotope types. With the help of spatial queries in GIS software, we linked the geographical positions of each 
of the 1,742 populations of the target species with the corresponding fine-grained biotope type and then aggregated the results at the level of the 12 major biotope classes.

\subsection{Ecological novelty}

To relate the locations of populations of endangered species to ecological novelty, we generated an ecosystem novelty map of Berlin (Fig. 1) by spatially combining data on biotope types with land use data as follows: We first assigned a preliminary novelty category to each of the 7,483 biotope types of the aforementioned biotope map. Following the approach of Kowarik and von der Lippe (2018), we classified biotope types by considering the origin of the type (natural vs. anthropogenic) and whether it is dominated by natural ecosystem processes or by human interference. This led to three novelty categories (adapted from Hobbs et al. 2009 and specified for urban settings by Kowarik and von der Lippe 2018):

- Natural remnant ecosystems are relicts of natural ecosystems that remain within their historical range of variability, although they are often slightly affected by urban impacts. Examples range from near-natural forests, mires and wetlands to moderately used dry or wet grasslands.

- Hybrid ecosystems are human-mediated ecosystems that have been modified from their historical state but still retain the potential to approach historical conditions. These include many young tree plantings in forests and parks, managed grasslands, urban green spaces, or low-intensity pastures. 
- Novel ecosystems are human-modified ecosystems that have likely been irreversibly changed by profound impacts on abiotic conditions or biotic composition. Novel ecosystems include built-up areas, vacant lots, rooftops, abandoned industrial areas, or high-intensity agricultural land.

While most biotope types could be easily classified into one of the novelty categories, this was challenging in some cases. Grassland biotopes, for example, include a range of nearnatural and anthropogenically shaped ecosystems in Berlin (Fischer et al. 2013b) and may thus be assigned to different novelty categories as illustrated in Fig. 2. To resolve this, we combined the biotope map with the Berlin Environmental Atlas's land use map (SenStadtUm 2015). Overlaying the two maps revealed that patches of grassland biotopes, for example, are associated with agricultural fields as well as with rooftops or sewage farms. The grassland patches in the two latter cases were assigned to novel ecosystems and those on agricultural fields to hybrid ecosystems (Fig. 2). In this way, we refined the preliminary novelty categorization to reduce uncertainties when the same biotope was found in different land uses. 


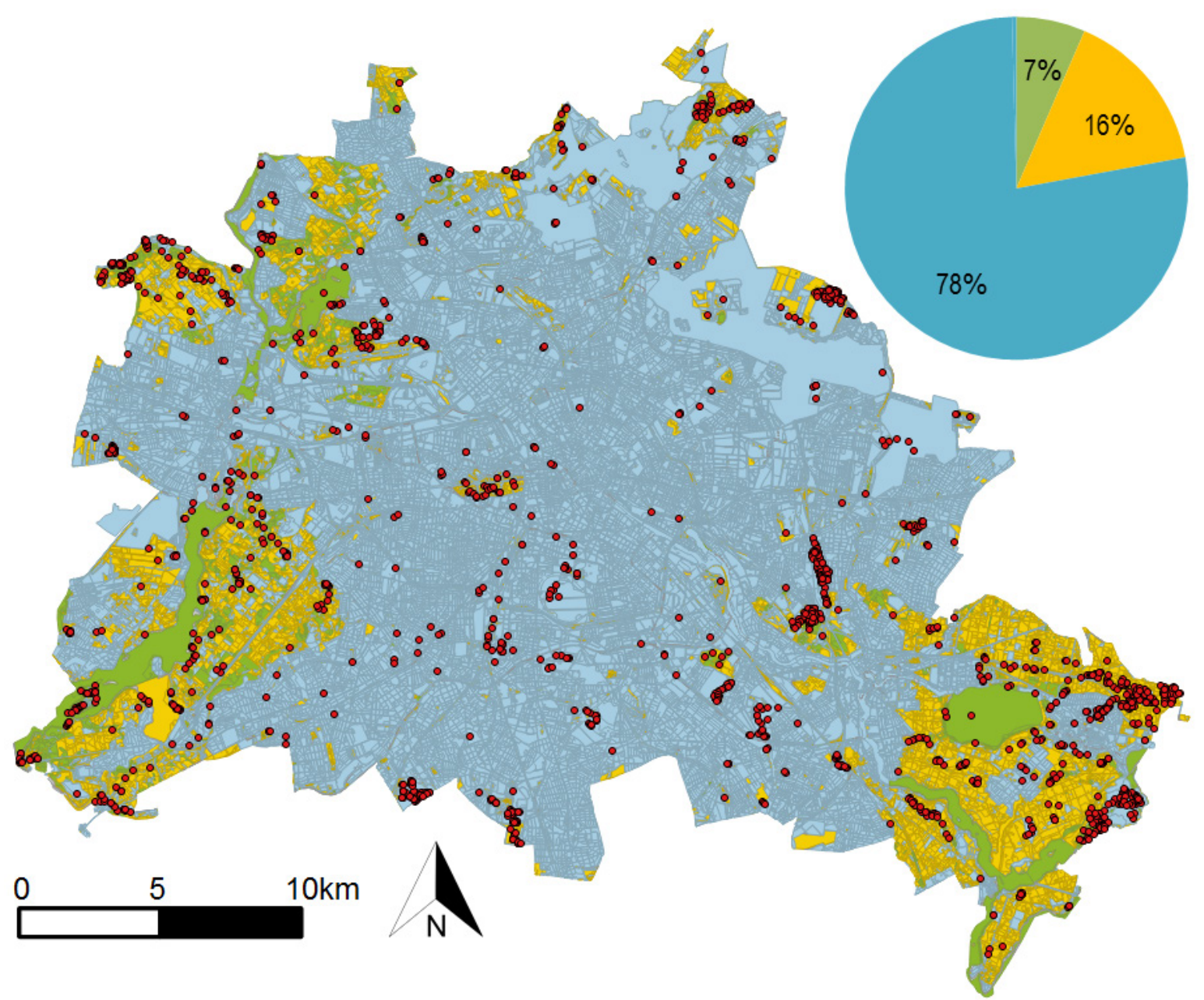

Fig. 1. Novelty map of Berlin with locations of populations ( $n=1742$; red dots) of endangered plant species $(n=213)$ that are priority species for biodiversity conservation in Berlin. Natural remnant ecosystems are shown in green, hybrid ecosystems in yellow, and novel ecosystems in blue. The pie chart displays the different surface area occupied by natural remnant, hybrid, and novel ecosystems. 


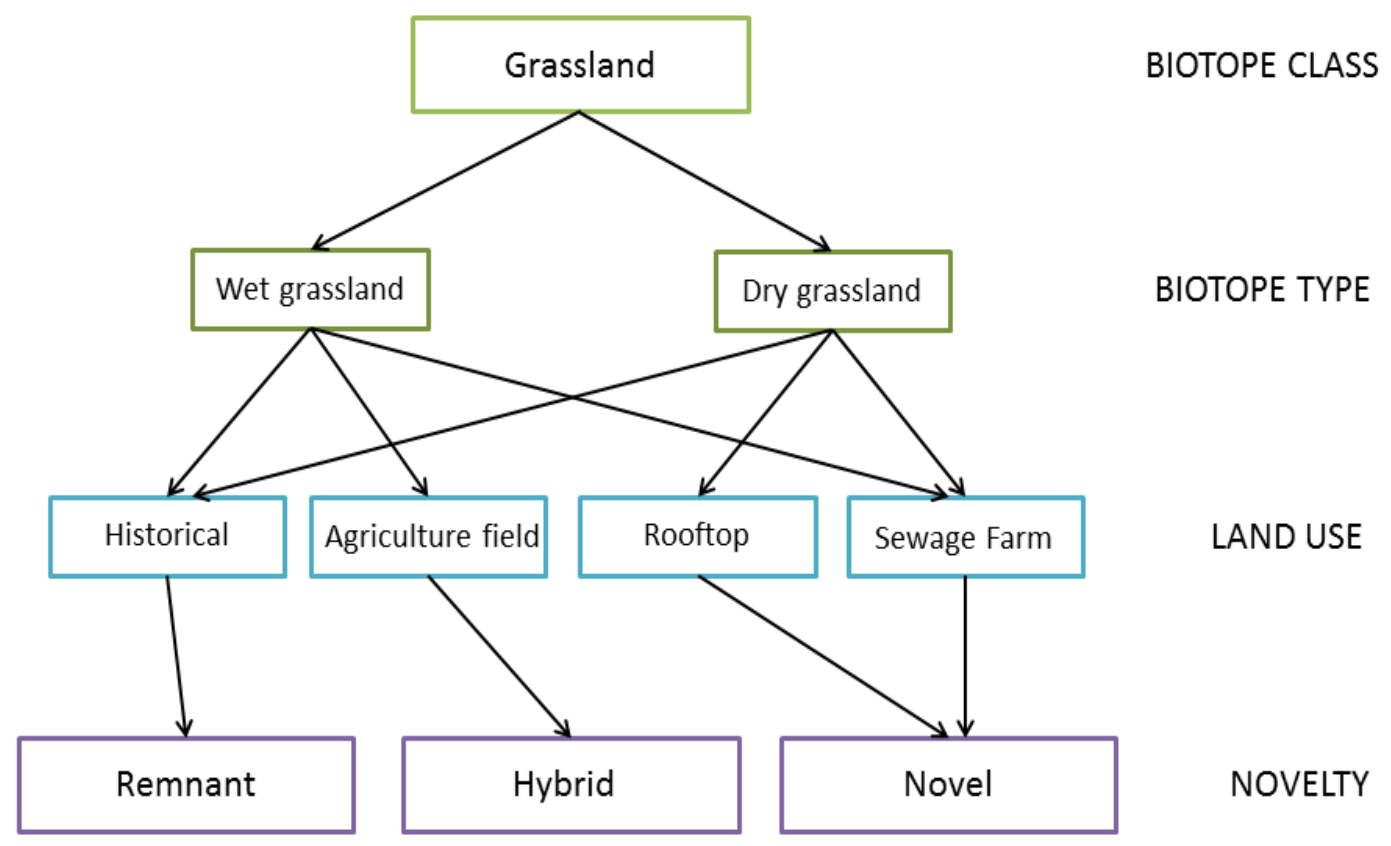

Fig. 2. Decision tree portraying the process of novelty categorization of biotope types, using the example of grassland biotopes, which can be assigned to different novelty categories depending on the land use type.

\subsection{Spatial and statistical analyses}

Merging the biotope map and the land use map to generate the novelty map was done by spatial intersections and later unions in Quantum-GIS (QGIS). To determine the biotope class and the ecosystem novelty type for the locations of the 1,742 populations, spatial intersections were performed in QGIS. To calculate the population density and the species density in a selected biotope class or novelty category, we divided the total number of populations or species by the total area of that class or category. We performed Spearman correlation analyses to test if the number and density of populations, or the number and density of species, that occur within each of the major 12 biotope classes correlates with the total size, or the average patch size, of biotope classes. 
To test for possible significant differences in mean densities of populations of endangered species between natural remnant, hybrid, and novel ecosystem patches, we performed a oneway permutation test based on a maxT statistic. This is similar to a one-way ANOVA but avoiding biased estimates due to non-normal distribution and zero inflation of the response. This procedure was followed by paired permutation tests with Holm correction to reveal significant differences between the three novelty categories.

To analyze how populations of endangered species from the 12 main biotope classes are distributed across the three novelty categories, we created a Sankey diagram by using the online tool SankeyMATIC (www.sankeymatic.com). Furthermore, we compared the differences in explained deviance of two log-linear models, one with and one without interaction of the two factors "biotope class" and "novelty category", using the counts of populations within either combination of the two factors as response. A significantly higher explained deviance in the interaction model would hereby indicate a significant dependence of the population counts in the novelty categories from certain biotope classes (and vice versa).

To elucidate whether natural remnants, hybrid, and novel ecosystems hold similar or distinct sets of endangered species, we generated an Euler diagram showing overlaps in the species pools of ecosystem types (eulerAPE: Micallef and Rodgers (2014)).

All statistical analyses were performed in R version 3.5.0 (R Core Team 2018). 


\section{Results}

\subsection{Biotope types}

Results showed that each of the 12 major biotope classes, which together cover all of the metropolitan area of Berlin, harbors some populations of endangered plant species—but with conspicuous differences among classes (Fig. 3, left). Most of the 1,742 populations (70\%) of the 213 high priority species were located within three biotope classes: forests (34\%), grasslands (26\%), and ruderal sites (10\%), while the remaining 30\% were spread throughout the other nine classes.

We tested for area effects on the presence of endangered species as the total area of biotope classes differed greatly (Fig. 3). Neither the total area of each biotope class nor its average patch size was significantly correlated with the number or density of populations or with the number or density of species that occurred within the respective biotope classes (Table 1).

\begin{tabular}{|c|c|c|c|c|}
\hline & \multicolumn{2}{|c|}{$\begin{array}{l}\text { Average area of } \\
\text { patches }\end{array}$} & \multicolumn{2}{|c|}{$\begin{array}{l}\text { Total area of biotope } \\
\text { class }\end{array}$} \\
\hline & rho & $P$ & rho & $P$ \\
\hline Total population number & -0.16 & 0.62 & 0.18 & 0.57 \\
\hline Density of populations (pop/km2) & -0.33 & 0.30 & -0.27 & 0.40 \\
\hline Total species number & -0.27 & 0.39 & 0.22 & 0.48 \\
\hline Density of species (sp/km2) & -0.33 & 0.29 & -0.27 & 0.40 \\
\hline
\end{tabular}

Table 1. Spearman correlations for relationships between the total area of each biotope 
class and its average patch area versus the number and density of populations $(n=1,742$ populations) and species ( $\mathrm{n}=213$ species $)$ inside of them.

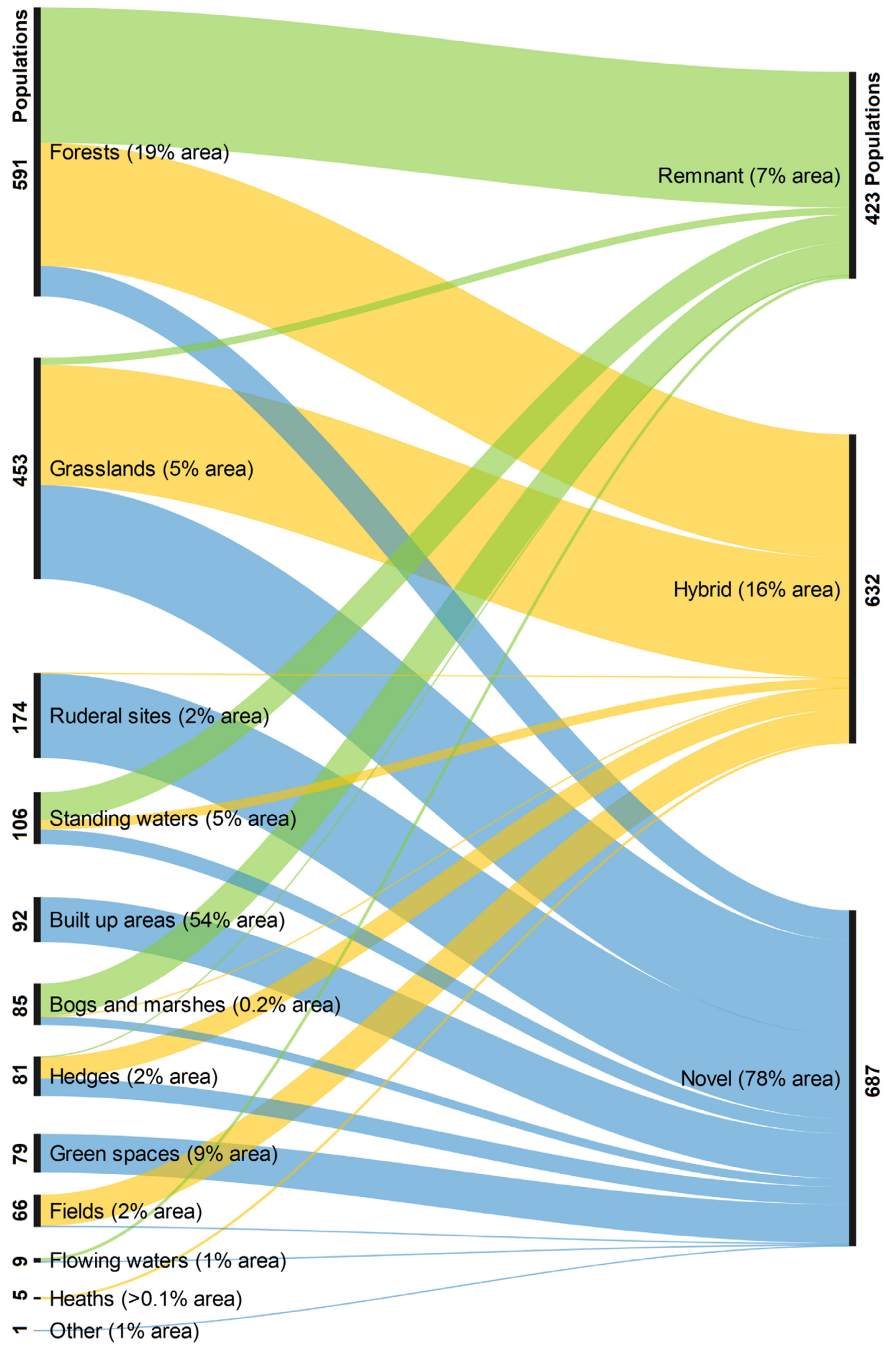


Fig. 3. Number of populations of 213 endangered plant species across biotope classes and types of ecological novelty in Berlin. The locations of 1,742 populations were assigned to 12 biotope classes (left) and to natural remnant, hybrid, or novel ecosystems (right). The width of the lines is proportional to the number of populations located in each combination of biotope class and novelty type. Numbers in parentheses show the share of biotope classes and novelty types within the total area of Berlin (total is not $100 \%$ due to rounding). The affiliation of populations to biotope classes and types of ecological novelty is not statistically independent, as revealed by a comparison of log-linear models with and without interaction of the two factors $(\mathrm{df}=22, \mathrm{p}<0.001)$. This means that populations from different biotope classes contribute significantly differently to the three types of ecological novelty.

\subsection{Ecological novelty}

Combining information about the fine-grained types of biotope with land use made it possible to assign the 79,268 patches of Berlin's biotope map to one of the three categories of ecological novelty. The resulting novelty map of Berlin (Fig. 1) revealed that natural remnants make up $7 \%$ of the area of Berlin, hybrid ecosystems $16 \%$, and novel ecosystems $78 \%$; the latter largely includes built-up areas and transportation corridors but also open spaces such as vacant urban-industrial land and sewage farms.

There were significant dependencies in the distribution of plant populations between the major biotope classes and the novelty categories, as revealed by the comparison of two loglinear models with and without interaction of the two factors $(\mathrm{df}=22, \mathrm{p}<0.001)$. Each novelty type harbored more than 400 populations of endangered species (Fig. 3, right). Surprisingly, novel ecosystems supported the highest number of populations (39.4\%), with the grassland 
and ruderal biotope classes most prominently represented. Hybrid ecosystems had a slightly smaller share of populations $(36.3 \%)$, and these were found mostly in forest and grassland biotopes. Only about one-fourth of all populations $(24.3 \%)$ were located in natural remnant ecosystems, with forest and wetland biotopes as major habitats. Population density, however, was significantly higher in natural remnants ( $0.12 \mathrm{pop} . / \mathrm{patch})$ compared to hybrid ( 0.04 pop./patch) and novel ecosystems (0.01 pop./patch) $($ Fig. 4 , $\operatorname{maxT}=17.108, \mathrm{p}<0.001)$. Species richness was similar in the two anthropogenic ecosystem categories (141 in hybrid, 142 in novel ecosystems), while only 102 species had populations in natural remnants.

Importantly, each novelty type harbored a considerable number of exclusive species (Fig. 5). Novel ecosystems had the highest share of exclusive species (20\%), followed by hybrid ecosystems (15\%), and natural remnant ecosystems (9\%). We also found important overlaps in shared species that were present in all novelty types (26\%) or two of the three novelty types (30\%; Fig. 5).

A

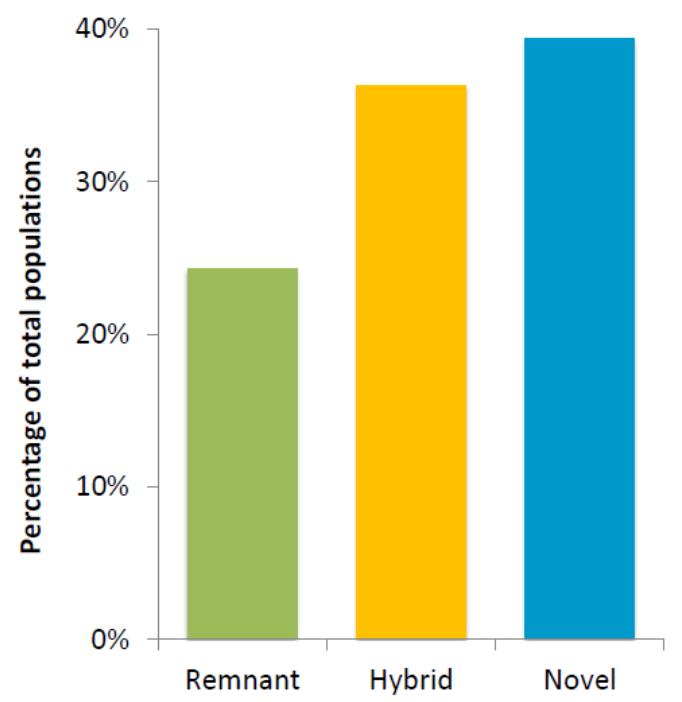

B

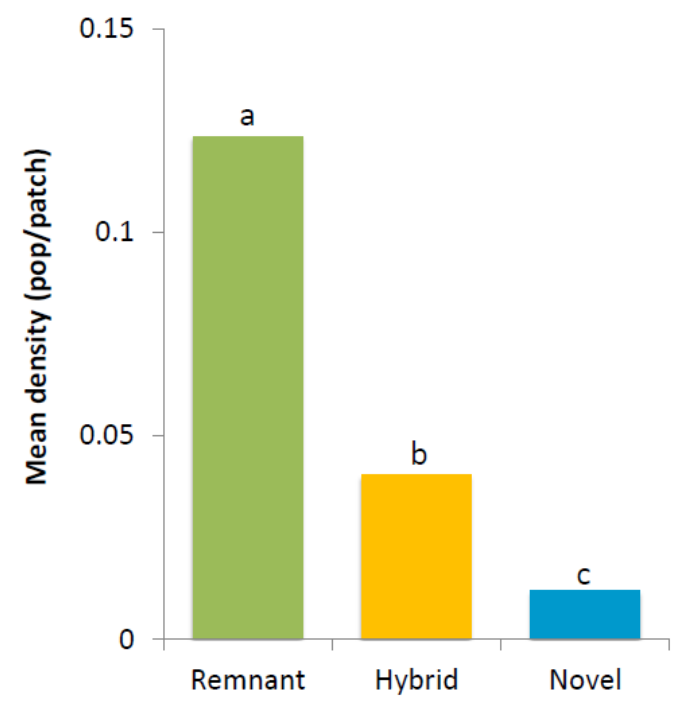

Fig. 4. A) Percentage of populations of endangered plant species $(100 \%=1,742$ populations $)$ and B) mean density of populations of endangered plant species in natural remnant, hybrid, 
and novel ecosystems. Significant differences in the mean density of populations between patches of natural remnant $(n=3,426)$, hybrid $(n=15,681)$ and novel ecosystems $(n=58,102)$ were determined by a one-way permutation test for the three groups: $\operatorname{maxT}=17.108$, $\mathrm{p}<0.001$. Different lower case letters above the bars indicate significant differences in mean population density between ecosystem types according to pairwise permutation tests with Holm correction.

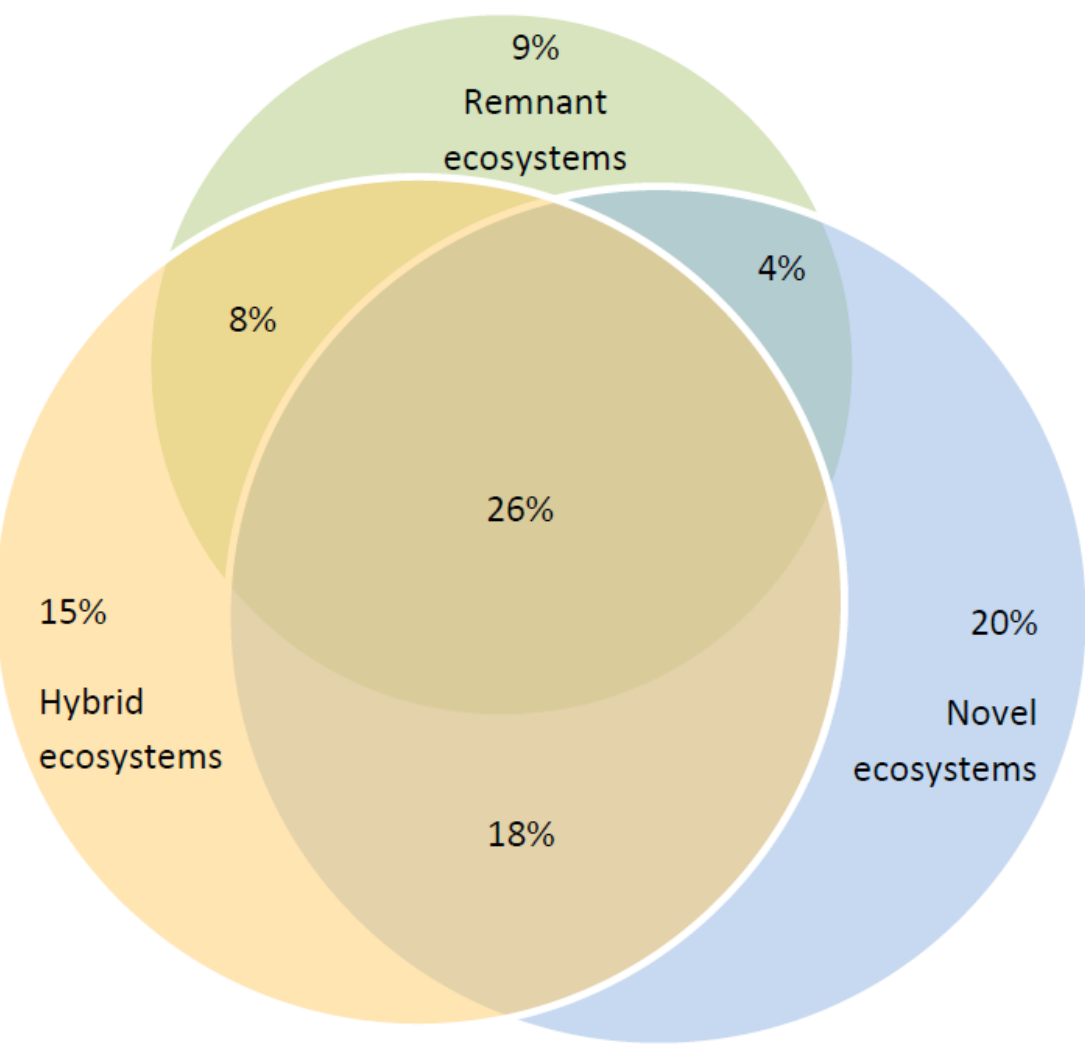

Fig. 5. Endangered plant species with shared or exclusive occurrences in natural remnant, hybrid, and novel ecosystems in Berlin $(100 \%=213$ species $)$, illustrated by an areaproportional Euler diagram. 


\section{Discussion}

Studies have revealed that urban regions have important potential for biodiversity conservation (Shwartz et al. 2014), but the trends for species of conservation concern are ambiguous: negative trends including population decline, extinctions (Hahs et al. 2009; Knapp et al. 2017), and biotic homogenization (Zeeman et al. 2017) as well as positive trends for population persistence and colonization of new habitats (Lawson et al. 2008; Lundholm \& Richardson 2010; Kowarik \& von der Lippe 2018) have been found. A key question for biodiversity conservation thus is not simply whether cities support biodiversity conservation, but which environmental settings within urban regions support species of conservation interest (Lepczyk et al. 2017).

This study is likely the first that quantifies the relative contribution of different biotope classes within a large metropolitan region for harboring populations of a large set of endangered plant species of the highest conservation priority at the city scale. Moreover, applying the novel ecosystem concept (Hobbs et al. 2013) to a fine-scaled map of biotope types revealed the importance that different levels of ecological novelty in urban ecosystems may have for endangered plant species.

\subsection{Biotope types}

Our analysis revealed conspicuous differences in habitat functions of biotope classes for populations of endangered plant species (Fig. 3). Built-up biotopes cover the majority of Berlin (54\%), but only 92 populations of endangered species were found there. The density of endangered species populations was highest in grassland and ruderal biotope classes, 
which together hosted $36 \%$ of all populations on $7 \%$ of the city area. These results demonstrate the importance of anthropogenically influenced biotopes for urban biodiversity conservation as grassland communities are absent in Berlin's natural vegetation (with a few exceptions for wetlands; Sukopp 1990). Previous studies have highlighted the conservation potential of urban grasslands, considering grasslands either as remnants of natural vegetation in other biogeographical regions (e.g., Cilliers et al. 2004; Zeeman et al. 2017) or as culturally shaped grassland types such as the ones in urban parks or airfields (e.g., Fischer et al. 2013a; Klaus 2013; Nielsen et al. 2014). This study substantiates the high importance of urban grassland biotopes by quantifying grassland populations of endangered plant species. Highly disturbed ruderal sites such as the ones found on vacant land or in transportation corridors usually fall outside the conservation focus. Recent studies have illustrated the potential of such sites for biodiversity or restoration efforts (Gardiner et al. 2013; Bonthoux et al. 2014; Anderson \& Minor 2017) and have documented the appreciation of biodiverse ruderal vegetation by urban people (Fischer et al. 2018). This study substantiates the relative importance ruderal biotopes may have for endangered plant species compared to other biotopes.

Forests biotopes, which represent the largest vegetation-dominated biotope class in Berlin (Fig. 3), provided habitats for the highest number of populations of endangered species. This unsurprising result corroborates previous studies about the significance of forest patches for urban biodiversity conservation (e.g. Godefroid and Koedam 2003; Diamond and Heinen 2016). Species that are strongly limited in their dispersal capacity, such as ancient forest species (Hermy et al. 1999; Dyderski et al. 2017), may be unable to colonize other urban biotopes and thus remain confined to forest biotopes with their long habitat continuity. 
Interestingly, the number of populations was neither significantly correlated with the area of biotope classes nor the mean area of patches within a biotope class (Table 1). This points to the greater importance of biotope class over patch size in supporting populations of endangered plant species. In contrast, the meta-analysis by Beninde et al. (2015) revealed patch area to be the most important predictor for urban biodiversity (i.e., species richness). Yet, this meta-analysis aggregated data from a large range of taxa with bird studies being overrepresented. As minimum size requirements for populations differ significantly across groups of taxa, patch size may be less relevant for plants. Our results thus indicate the importance of even small biotope patches for endangered plants in cities. Correspondingly, a recent Australian study highlighted the importance of both big and small urban conservation areas for plant species of conservation interest (Kendal et al. 2017).

\subsection{Ecological novelty}

Urbanization implies the step-by-step transformation of natural to anthropogenically disturbed ecosystems. Among the latter, a range of novel ecosystem types have emerged following the destruction or profound alterations of former ecosystems (Kowarik 2011). Considering the ecological features, current land use, and the history of urban sites allows deeper insights into the response of species to urbanization (Ramalho \& Hobbs 2012). We approached this challenge by overlaying biotope maps with land use maps. This allowed us to differentiate among novelty categories sometimes even within the same type of biotope (e.g., grassland biotopes, Fig. 2).

The prominence of novel ecosystems in harboring the largest number of populations of endangered plant species in Berlin is a major and unexpected result of this study. Former 
studies have shown the potential of novel urban ecosystems for native and some endangered species (e.g., Lundholm and Richardson 2010; Bonthoux et al. 2014)—but without quantifying novel habitat functions in relation to others (but see case study from Maclagan et al. 2018). As an exception, a previous study from Berlin revealed a considerable number of native and endangered species in novel ecosystems, but with clearly more in natural remnants (Kowarik \& von der Lippe 2018). That the present study was able to reveal an even higher importance of novel ecosystems for endangered species is likely due to methodological reasons. The previous study relied on a dataset with expert ratings on the occurrence of about 1200 species across novelty categories. In contrast, here we used a current data set on a smaller subset of species of highest conservation concern $(n=213)$, with information about 1,742 spatially referenced populations. Relating these data to the level of ecological novelty of each biotope patch, and to aggregate fine-grained novelty assessments ultimately to the three major novelty categories, likely yielded more precise insights into the relevance of ecological novelty for endangered plant species in cities.

However, the data analysed also revealed a twelve times higher density of endangered species in natural remnant compared to novel ecosystems and a more than four times higher density in hybrid compared to novel ecosystems (Fig. 4). In terms of cost efficiency of practical conservation measures, it may still be more efficient to preserve the same amount of habitat in natural remnant than in novel ecosystems. The rather low density of endangered species in novel ecosystems mainly resulted from the inclusion of a large amount of built-up areas with sealed surfaces. Although excluding these areas would have possibly modified this relationship, it was not possible due to an unknown extent of the sealed surface. 
Analyzing the overlap of species pools across the three novelty categories revealed a considerable number of species that occur exclusively in one category, with 9-20\% of species confined to one novelty category, and surprisingly, of these most were confined to novel ecosystems (Fig. 5). These results provide further evidence on the importance of biotopes across all novelty categories for urban biodiversity conservation. One novelty category can thus not substitute for the habitat functions of another category. It should be noted, however, that the density of endangered populations $/ \mathrm{km}^{2}$ was higher in natural remnants (7.3) than in hybrid (4.5) and novel ecosystems (1.0).

The high share of species that were only found in novel ecosystems is likely due to the urbanization-mediated habitat transformation of natural remnants or historical agrarian ecosystems. Even some dispersal-limited species may occur in novel ecosystems owing to human-mediated dispersal pathways that can counteract spatial isolation. For example, nongeneralist grassland species are often dispersal limited (Deák et al. 2018), but they can nonetheless be found on ca. 100-year-old rooftops of waterworks in Berlin (data not shown), suggesting historical practices of transferring seeds, sods, or natural soil from near-natural settings for rooftop greening (Brenneisen 2006; Jim 2017).

It is important to note that, due to a range of human-mediated environmental barriers (Williams et al. 2009; Kowarik \& von der Lippe 2018), not all urban populations of a given plant species are ultimately successful at establishment, and some may be at risk of extirpation (Hahs \& McDonnell 2014). A study on the performance of rare plant species along California's coastline found no correlation between species' performance and human population density (Schwartz et al. 2013). However, of all species that were documented for different types of anthropogenic, hybrid, or novel ecosystems in Berlin, 21-57\% had only 
casual populations, i.e., these species were not able to establish self-sustaining populations in cultural ecosystems (Kowarik \& von der Lippe 2018). The urban success of endangered species indicated by the present study may thus be overestimated until casual or decreasing populations are accounted for. Untangling the long-term population performance of endangered species across urban biotope classes is thus an important future direction. 


\section{Conclusions}

While the urban contribution to biodiversity conservation is increasingly highlighted in conservation policies and management approaches (e.g., Aronson et al. 2017, Garrard et al. 2018), important barriers to investing in urban conservation efforts still remain. Soanes et al. (2018) recently complained of "a pervasive narrative in policy, practice and the public psyche" that urban environments offer limited conservation value; the authors argued for making use of small spaces and unconventional habitats. By quantifying the relative importance of novel urban ecosystems for plant species of high conservation priority in a metropolitan region, this study provides strong support for making use of the opportunities that unconventional habitats offer for biodiversity conservation in urban regions. At the same time, results also demonstrate that neither novel nor traditional ecosystems alone were able to harbor all plant species of high conservation concern in Berlin. This study thus further supports a diversified urban conservation approach to cover the potential of all types of urban ecosystems for biodiversity conservation.

Acknowledgements: We thank Justus Meißner and Stiftung Naturschutz Berlin for sharing the population data, and Berlin's Senate Department for the Environment, Transport and Climate Protection for providing GIS layers of biotope and land use maps. We also thank Kelanie Ravdin for comments on the manuscript. GP was funded by the Hans Böckler Foundation, and parts of this study were funded by the German Federal Ministry of Education and Research BMBF within the Collaborative Project "Bridging in Biodiversity Science-BIBS” (funding number 01LC1501A-H). 


\section{Literature cited}

Anderson EC, Minor ES. 2017. Vacant lots: An underexplored resource for ecological and social benefits in cities. Urban Forestry \& Urban Greening 21:146-152.

Aronson MF, et al. 2016. Hierarchical filters determine community assembly of urban species pools. Ecology 97:2952-2963.

Aronson MFJ, Lepczyk CA, Evans KL, Goddard MA, Lerman SB, MacIvor JS, Nilon CH, Vargo T. 2017. Biodiversity in the city: key challenges for urban green space management. Frontiers in Ecology and the Environment 15:189-196.

Beninde J, Veith M, Hochkirch A. 2015. Biodiversity in cities needs space: a meta-analysis of factors determining intra-urban biodiversity variation. Ecol Lett 18:581-592.

Bonthoux S, Brun M, Di Pietro F, Greulich S, Bouché-Pillon S. 2014. How can wastelands promote biodiversity in cities? A review. Landscape and urban planning 132:79-88.

Brenneisen S. 2006. Space for urban wildlife: designing green roofs as habitats in Switzerland. Urban habitats 4.

Cilliers SS, Müller N, Drewes E. 2004. Overview on urban nature conservation: situation in the western-grassland biome of South Africa. Urban Forestry \& Urban Greening $3: 49-62$.

Deak B, Valko O, Torok P, Kelemen A, Bede A, Csatho AI, Tothmeresz B. 2018. Landscape and habitat filters jointly drive richness and abundance of specialist plants in terrestrial habitat islands. Landscape Ecology 33:1117-1132.

Diamond JM, Heinen JT. 2016. Conserving rare plants in locally-protected urban forest fragments: A case study from Miami-Dade County, Florida. Urban Forestry \& Urban Greening 20:1-11.

Dyderski MK, Tyborski J, Jagodzinski AM. 2017. The utility of ancient forest indicator species in urban environments: A case study from Poznan, Poland. Urban Forestry \& Urban Greening 27:76-83.

Ellis EC. 2015. Ecology in an anthropogenic biosphere. Ecological Monographs 85:287-331.

Fischer LK, et al. 2018. Beyond green: Broad support for biodiversity in multicultural European cities. Global Environmental Change-Human and Policy Dimensions 49:3545.

Fischer LK, von der Lippe M, Kowarik I. 2013a. Urban grassland restoration: which plant traits make desired species successful colonizers? Applied Vegetation Science $16: 272-285$. 
Fischer LK, von der Lippe M, Kowarik I. 2013b. Urban land use types contribute to grassland conservation: The example of Berlin. Urban Forestry \& Urban Greening $12: 263-272$.

Gardiner MM, Burkman CE, Prajzner SP. 2013. The value of urban vacant land to support arthropod biodiversity and ecosystem services. Environ Entomol 42:1123-1136.

Garrard GE, Williams NSG, Mata L, Thomas J, Bekessy SA. 2018. Biodiversity Sensitive Urban Design. Conservation Letters 11:e12411.

Goddard MA, Dougill AJ, Benton TG. 2010. Scaling up from gardens: biodiversity conservation in urban environments. Trends Ecol Evol 25:90-98.

Godefroid S, Koedam N. 2003. How important are large vs. small forest remnants for the conservation of the woodland flora in an urban context? Global Ecology and Biogeography 12:287-298.

Guneralp B, Seto KC. 2013. Futures of global urban expansion: uncertainties and implications for biodiversity conservation. Environmental Research Letters 8:014025.

Hahs AK, McDonnell MJ. 2014. Extinction debt of cities and ways to minimise their realisation: a focus on Melbourne. Ecological Management \& Restoration 15:102110.

Hahs AK, et al. 2009. A global synthesis of plant extinction rates in urban areas. Ecol Lett 12:1165-1173.

Hermy M, Honnay O, Firbank L, Grashof-Bokdam C, Lawesson JE. 1999. An ecological comparison between ancient and other forest plant species of Europe, and the implications for forest conservation. Biological Conservation 91:9-22.

Hobbs RJ, et al. 2014. Managing the whole landscape: historical, hybrid, and novel ecosystems. Frontiers in Ecology and the Environment 12:557-564.

Hobbs RJ, Higgs E, Harris JA. 2009. Novel ecosystems: implications for conservation and restoration. Trends Ecol Evol 24:599-605.

Hobbs RJ, Higgs ES, Hall C 2013. Novel ecosystems: intervening in the new ecological world order. John Wiley \& Sons.

Ives CD, et al. 2016. Cities are hotspots for threatened species. Global Ecology and Biogeography 25:117-126.

Jim CY. 2017. An archaeological and historical exploration of the origins of green roofs. Urban Forestry \& Urban Greening 27:32-42. 
Kendal D, Zeeman BJ, Ikin K, Lunt ID, McDonnell MJ, Farrar A, Pearce LM, Morgan JW. 2017. The importance of small urban reserves for plant conservation. Biological Conservation 213:146-153.

Klaus VH. 2013. Urban Grassland Restoration: A Neglected Opportunity for Biodiversity Conservation. Restoration Ecology 21:665-669.

Knapp S, Kühn I, Mosbrugger V, Klotz S. 2008. Do protected areas in urban and rural landscapes differ in species diversity? Biodiversity and Conservation 17:1595-1612.

Knapp S, Winter M, Klotz S. 2017. Increasing species richness but decreasing phylogenetic richness and divergence over a 320-year period of urbanization. Journal of Applied Ecology 54:1152-1160.

Kowarik I. 2011. Novel urban ecosystems, biodiversity, and conservation. Environ Pollut 159:1974-1983.

Kowarik I, von der Lippe M. 2018. Plant population success across urban ecosystems: A framework to inform biodiversity conservation in cities. Journal of Applied Ecology 55:2354-2361.

Kuhn I, Brandl R, Klotz S. 2004. The flora of German cities is naturally species rich. Evolutionary Ecology Research 6:749-764.

Lawson DM, Lamar CK, Schwartz MW. 2008. Quantifying plant population persistence in human-dominated landscapes. Conserv Biol 22:922-928.

Lenzen M, Lane A, Widmer-Cooper A, Williams M. 2009. Effects of land use on threatened species. Conserv Biol 23:294-306.

Lepczyk CA, Aronson MFJ, Evans KL, Goddard MA, Lerman SB, Macivor JS. 2017. Biodiversity in the City: Fundamental Questions for Understanding the Ecology of Urban Green Spaces for Biodiversity Conservation. Bioscience 67:799-807.

Lundholm JT, Richardson PJ. 2010. MINI-REVIEW: Habitat analogues for reconciliation ecology in urban and industrial environments. Journal of Applied Ecology 47:966975.

Maclagan SJ, Coates T, Ritchie EG. 2018. Don't judge habitat on its novelty: Assessing the value of novel habitats for an endangered mammal in a peri-urban landscape. Biological Conservation 223:11-18.

Mcdonald RI, Kareiva P, Formana RTT. 2008. The implications of current and future urbanization for global protected areas and biodiversity conservation. Biological Conservation 141:1695-1703. 
McDonnell MJ, Hahs AK. 2015. Adaptation and Adaptedness of Organisms to Urban Environments. Annual Review of Ecology, Evolution, and Systematics, Vol 46 46:261-280.

McKinney ML. 2008. Effects of urbanization on species richness: A review of plants and animals. Urban Ecosystems 11:161-176.

Micallef L, Rodgers P. 2014. eulerAPE: drawing area-proportional 3-Venn diagrams using ellipses. PLoS One 9:e101717.

Nielsen AB, van den Bosch M, Maruthaveeran S, van den Bosch CK. 2014. Species richness in urban parks and its drivers: A review of empirical evidence. Urban Ecosystems 17:305-327.

Nilon CH, et al. 2017. Planning for the Future of Urban Biodiversity: A Global Review of City-Scale Initiatives. Bioscience 67:331-341.

R Core Team. 2018. R: A Language and Environment for Statistical Computing.

Ramalho CE, Hobbs RJ. 2012. Time for a change: dynamic urban ecology. Trends Ecol Evol 27:179-188.

Schwartz MW, Jurjavcic NL, O'Brien JM. 2002. Conservation's disenfranchised urban poor. Bioscience 52:601-606.

Schwartz MW, Smith LM, Steel ZL. 2013. Conservation investment for rare plants in urban environments. PLoS One 8:e83809.

Seitz B, Ristow M, Meißner J, Machatzi B, Sukopp H 2018. Rote Liste und Gesamtartenliste der etablierten Farn-und Blütenpflanzen von Berlin. Universitätsverlag der TU Berlin.

SenStadtUm. 2014. Berlin Environmental Atlas, Biotope Types.

SenStadtUm. 2015. Actual Use of Built-up Areas, Inventory of Green and Open Spaces, Actual Use and Vegetation Cover.

SenStadtUm. 2016. Berlin Environmental Atlas, Map Actual Use and Vegetation.

Shwartz A, Turbe A, Julliard R, Simon L, Prevot AC. 2014. Outstanding challenges for urban conservation research and action. Global Environmental Change-Human and Policy Dimensions 28:39-49.

Soanes K, Sievers M, Chee YE, Williams NSG, Bhardwaj M, Marshall AJ, Parris KM. 2018. Correcting common misconceptions to inspire conservation action in urban environments. Conserv Biol. 
Stiftung Naturschutz Berlin. 2015. Koordinierungsstelle Florenschutz - ein Projekt zur Umsetzung des Florenschutzkonzeptes Berlin.

Sukopp H. 1987. On the history of plant geography and plant ecology in Berlin. Englera $7: 85-103$.

Sukopp H. 1990. Stadtökologie. Das Beispiel Berlin.-Berlin: D. Reimer Verlag.-1990.-455 s.

Sukopp H, Weiler S. 1988. Biotope Mapping and Nature Conservation Strategies in Urban Areas of the Federal-Republic-of-Germany. Landscape and Urban Planning 15:39-58.

Williams NSG, et al. 2009. A conceptual framework for predicting the effects of urban environments on floras. Journal of Ecology 97:4-9.

Zeeman BJ, McDonnell MJ, Kendal D, Morgan JW. 2017. Biotic homogenization in an increasingly urbanized temperate grassland ecosystem. Journal of Vegetation Science 28:550-561.

Zeeman BJ, Morgan JW. 2018. Increasing and declining native species in urban remnant grasslands respond differently to nitrogen addition and disturbance. Ann Bot 121:691697. 
Appendix A Target species of Berlin's Flora Protection Program with information on the Red List status in Berlin (according to Seitz et al. 2018): 0 extinct or disappeared; 1 threatened with extinction; 2 highly endangered; 3 compromised; $\mathrm{G}$ danger of unknown extent; R extremely rare; V early warning list; D data insufficient; * safe; and the total number of populations in our study. The categories of the Red List refer species' population status in Berlin, with the situation in the mid- $19^{\text {th }}$ century as baseline.

\begin{tabular}{|c|c|c|c|c|c|}
\hline \multirow{3}{*}{ Species } & \multirow{3}{*}{$\begin{array}{l}\frac{\text { Red }}{\text { List }} \\
\underline{\text { Status }}\end{array}$} & \multirow{3}{*}{$\begin{array}{l}\text { Number of } \\
\text { Populations }\end{array}$} & \multirow{3}{*}{$\begin{array}{l}\text { Carex lepidocarpa } \\
\text { Carex ligerica } \\
\text { Carex limosa }\end{array}$} & \multirow{3}{*}{$\begin{array}{l}1 \\
V \\
1\end{array}$} & 5 \\
\hline & & & & & 14 \\
\hline & & & & & 13 \\
\hline \multirow{3}{*}{$\begin{array}{l}\text { Agrimonia procera } \\
\text { Aira caryophyllea subsp. } \\
\text { caryophyllea }\end{array}$} & 1 & 14 & Carex otrubae & 1 & 2 \\
\hline & \multirow{2}{*}{1} & \multirow{2}{*}{5} & Carex pseudobrizoides & 1 & 3 \\
\hline & & & Carex supina & 1 & 10 \\
\hline \multirow{2}{*}{$\begin{array}{l}\text { Ajuga reptans } \\
\text { Alchemilla monticola }\end{array}$} & 1 & 5 & Carex viridula subsp. & \multirow{2}{*}{1} & \\
\hline & 1 & 2 & viridula & & \\
\hline Alchemilla plicata & 0 & 3 & Carlina vulgaris agg. & 1 & 18 \\
\hline Alchemilla subcrenata & 1 & 1 & Catabrosa aquatica & 1 & 3 \\
\hline Alisma lanceolatum & 1 & 2 & Centaurea diffusa & 1 & 3 \\
\hline Allium angulosum & 1 & 1 & Centaurium erythraea & 2 & 1 \\
\hline Alyssum alyssoides & 1 & 5 & Centaurium pulchellum & 1 & 9 \\
\hline Andromeda polifolia & 1 & 8 & Chenopodium bonus- & 0 & 1 \\
\hline Anemone & 2 & 8 & henricus & 0 & 1 \\
\hline ranunculoides & 2 & $\gamma$ & Chenopodium murale & 1 & 7 \\
\hline Antennaria dioica & 0 & 1 & Chimaphila umbellata & 0 & 2 \\
\hline Anthericum ramosum & 2 & 1 & Chrysosplenium & 1 & 6 \\
\hline Anthyllis vulneraria s. & 1 & 17 & alternifolium & 1 & 0 \\
\hline$l$. & & & Cicuta virosa & 2 & 15 \\
\hline Arnoseris minima & 1 & 8 & Colchicum autumnale & 1 & 3 \\
\hline Asperula tinctoria & 1 & 4 & Consolida regalis & 1 & 15 \\
\hline Asplenium trichomanes & 2 & 1 & Corydalis intermedia & 1 & 3 \\
\hline Astragalus arenarius & 1 & 3 & Crataegus macrocarpa & 1 & 6 \\
\hline Astragalus danicus & 1 & 5 & Crataegus media & 1 & 1 \\
\hline Blysmus compressus & 1 & 2 & Crataegus & 1 & 1 \\
\hline Botrychium lunaria & 1 & 26 & rhipidophylla s. str. & 1 & 1 \\
\hline $\begin{array}{l}\text { Botrychium } \\
\text { matricariifolium }\end{array}$ & 1 & 20 & $\begin{array}{l}\text { Crataegus } \\
\text { subsphaericea }\end{array}$ & 1 & 10 \\
\hline Botrychium multifidum & 0 & 2 & Cuscuta epithymum & 1 & 6 \\
\hline Cannabis sativa s. $l$. & 1 & 1 & Cuscuta lupuliformis & 1 & 1 \\
\hline Carex appropinquata & 2 & 21 & Cystopteris fragilis s. & & \\
\hline Carex cespitosa & 1 & 9 & str. & 1 & \\
\hline Carex demissa & 1 & 1 & Dactylis polygama & G & 19 \\
\hline Carex diandra & 1 & 3 & Dactylorhiza incarnata & 1 & 15 \\
\hline Carex hartmanii & 1 & 37 & Dactylorhiza maculata & 1 & 10 \\
\hline
\end{tabular}


agg.

Hieracium bauhini

Dactylorhiza majalis s.

subsp. heothinum

Hieracium caespitosum 1112

Dactylorhizax

Hieracium fallax subsp.

durisetum

aschersoniana

Hieracium maculatum

Dianthus

carthusianorum

Dianthus superbus $\quad 1 \quad 16$

subsp. fictum

Hieracium maculatum

Drosera intermedia $\quad 1 \quad 2$

Drosera rotundifolia 11

$\begin{array}{lll}\text { Dryopteris cristata } & 1 & 6\end{array}$

Elatine alsinastrum $\quad 1 \quad 2$

Epilobium obscurum 11

Epipactis palustris $\quad 1 \quad 1$

$\begin{array}{lll}\text { Equisetum sylvaticum } & 1 & 6\end{array}$

Equisetum variegatum $\quad 0 \quad 1$

Erigeron

droebachiensis

Euphorbia palustris 115

Euphrasia nemorosas. 0 l.

Euphrasia stricta $\quad 1 \quad 16$

Festuca polesica $\quad 1 \quad 1$

Festuca psammophila 1

Filago minima $\quad 2 \quad 15$

Filago vulgaris $\quad 1 \quad 4$

Filipendula vulgaris 223

Fragaria viridis $\quad 1 \quad 11$

Galeobdolon luteum $\quad$ G $\quad 16$

Galeopsis ladanum $\quad 0 \quad 1$

subsp. tinctum

Hieracium prussicum

subsp. trichotum

Hierochloe hirta subsp.

praetermissa

Hierochloe odorata

subsp. odorata

Hippuris vulgaris

Hydrocharis morsus-

ranae

Hypericum desetangsii

nothosubsp.

carinthiacum

Hypericum maculatum 1

s. str.

Hypochaeris glabra $\quad 0 \quad 1$

Hypopitys monotropas. 1

str.

Impatiens noli-tangere 11

Inula salicina $\quad 1 \quad 3$

$\begin{array}{lll}\text { Iris sibirica } & 1 & 36\end{array}$

$\begin{array}{lll}\text { Isolepis setacea } & 1 & 4\end{array}$

Galium pumilum s. str. $\quad 0 \quad 1$

Genista germanica $\quad 1 \quad 4$

Genista tinctoria $\quad 1 \quad 28$

Gentiana

pneumonanthe

Juncus

alpinoarticulatus $\quad 1 \quad 2$

Juncus capitatus $\quad 0 \quad 1$

Juncus filiformis 115

Juncus subnodulosus 223

Juncus tenageia $\quad 1 \quad 2$

Juniperus communis 132

Geranium sanguineum 1

Gypsophila muralis $\quad 0 \quad 2$

Helianthemum

subsp. communis

nummularium subsp. $\quad 1 \quad 1$

Koeleria glauca $\quad 1$

Lathraea squamaria $\quad 1 \quad 14$

obscurum

Leersia oryzoides 115

Helictotrichon pratense 112

$\begin{array}{lll}\text { Hepatica nobilis } & 1 & 4\end{array}$

Lotus tenuis $\quad 1 \quad 5$

Luzula pallescens $\quad 1 \quad 4$ 


\begin{tabular}{|c|c|c|c|c|c|}
\hline Lychnis viscaria & 1 & 7 & subsp. peltatus & & \\
\hline Lycopodium annotinum & 1 & 2 & Ranunculus sardous & 1 & 22 \\
\hline Lythrum hyssopifolia & 0 & 2 & Ranunculus & 1 & 7 \\
\hline Medicago minima & 2 & 9 & trichophyllus s. $l$. & 1 & l \\
\hline Myosotis discolor & 0 & 1 & Rhinanthus minor & 1 & 32 \\
\hline Myosotis sparsiflora & 2 & 7 & Rhododendron & 1 & \\
\hline Myosurus minimus & 1 & 13 & tomentosum & 1 & \\
\hline Najas marina subsp. & $G$ & 3 & Rhynchospora alba & 1 & 7 \\
\hline intermedia & U & 3 & Rosa caesia s. str. & 1 & 3 \\
\hline Najas marina subsp. & & 10 & Rosa dumalis & 1 & 35 \\
\hline marina & 1 & 10 & Rosa elliptica & 1 & 4 \\
\hline Noccaea caerulescens & 0 & 2 & Rosa marginata & 0 & 1 \\
\hline $\begin{array}{l}\text { Oenothera parviflora s. } \\
\text { str. }\end{array}$ & 1 & 2 & $\begin{array}{l}\text { Rosa } \\
\text { pseudoscabriuscula }\end{array}$ & 1 & 1 \\
\hline Orchis militaris & 1 & 10 & Rubus fasciculatiformis & 1 & 1 \\
\hline Osmunda regalis & 1 & 28 & Rumex aquaticus & 0 & 2 \\
\hline Parnassia palustris & 1 & 3 & Rumex sanguineus & 1 & 20 \\
\hline Platanthera bifolia & 1 & 8 & Sagina apetala agg. & $\mathrm{D}$ & 2 \\
\hline Populus nigra & $\mathrm{G}$ & 103 & Sagina nodosa & 1 & 8 \\
\hline $\begin{array}{l}\text { Potamogeton } \\
\text { acutifolius }\end{array}$ & 1 & 7 & $\begin{array}{l}\text { Sanguisorba minor } \\
\text { subsp. minor }\end{array}$ & 1 & 14 \\
\hline Potamogeton friesii & 1 & 2 & Scabiosa canescens & 1 & 4 \\
\hline Potamogeton & 0 & 4 & Scilla amoena & $\mathrm{R}$ & 4 \\
\hline gramineus & 0 & 4 & Scolochloa festucacea & 0 & 2 \\
\hline Potamogeton lucens & 1 & 6 & Scorzonera humilis & 2 & 55 \\
\hline Potamogeton nodosus & 1 & 3 & Scorzonera purpurea & 1 & 1 \\
\hline Potamogeton & 1 & 5 & Selinum dubium & 1 & 15 \\
\hline obtusifolius & 1 & 5 & Senecio paludosus & 1 & 10 \\
\hline $\begin{array}{l}\text { Potamogeton } \\
\text { perfoliatus }\end{array}$ & 1 & 2 & $\begin{array}{l}\text { Serratula tinctoria } \\
\text { subsp. tinctoria }\end{array}$ & 1 & 23 \\
\hline Potamogeton pusillus & $\mathrm{G}$ & 7 & Silene chlorantha & 2 & 2 \\
\hline Potentilla alba & 1 & 17 & Silene conica & 1 & 21 \\
\hline Potentilla heptaphylla & 1 & 2 & Silene noctiflora & 1 & 2 \\
\hline Primula veris & 1 & 6 & Silene otites & 1 & 24 \\
\hline Pulicaria dysenterica & 0 & 1 & Silene tatarica & 3 & 23 \\
\hline Pulsatilla pratensis & 1 & 5 & Sparganium natans & 1 & 3 \\
\hline subsp. nigricans & 1 & 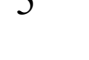 & Stipa capillata & 1 & 1 \\
\hline Pyrola chlorantha & 1 & 2 & Stipa pennata s. str. & 1 & 2 \\
\hline Pyrola minor & 1 & 1 & Stratiotes aloides & 2 & 10 \\
\hline Ranunculus aquatilis & 1 & 17 & Swertia perennis & 0 & 1 \\
\hline Ranunculus circinatus & 1 & 1 & Taraxacum nordstedtii & 0 & 2 \\
\hline Ranunculus lingua & 1 & 15 & Tephroseris palustris & 1 & 3 \\
\hline Ranunculus peltatus & 1 & 1 & Teucrium scordium & 1 & 1 \\
\hline
\end{tabular}


subsp. scordium

Thalictrum minus

subsp. minus

Thelypteris

limbosperma

Tragopogon orientalis

Trifolium alpestre

Trifolium montanum

Tulipa sylvestris

Urtica kioviensis

Utricularia australis

Utricularia minor s. str.

Utricularia vulgaris $\quad 1 \quad 6$

Verbena officinalis $\quad 1 \quad 16$

Veronica polita $\quad 2 \quad 8$

Veronica praecox $\quad 1 \quad 1$

$\begin{array}{lll}\text { Viola hirta } & 1 & 3\end{array}$

Viola rupestris $\quad 1 \quad 15$

Viola stagnina $\quad 0 \quad 2$

Vulpia myuros $\quad 3 \quad 4$

Wolffia arrhiza $\quad 2 \quad 1$

Zannichellia palustris 1 
Appendix B Visual summary of the methodological process of this study. Green boxes represent the data sources, blue boxes represent the methodological procedures, and white boxes represent the data generated from each of the methodological procedures. Lines indicate which data are used in each procedure. Boxes are grouped in columns according to the scale or framework used at different stages.

\section{POPULATIONS}

Endangered species: 1742 populations 213 species
BIOTOPE TYPES

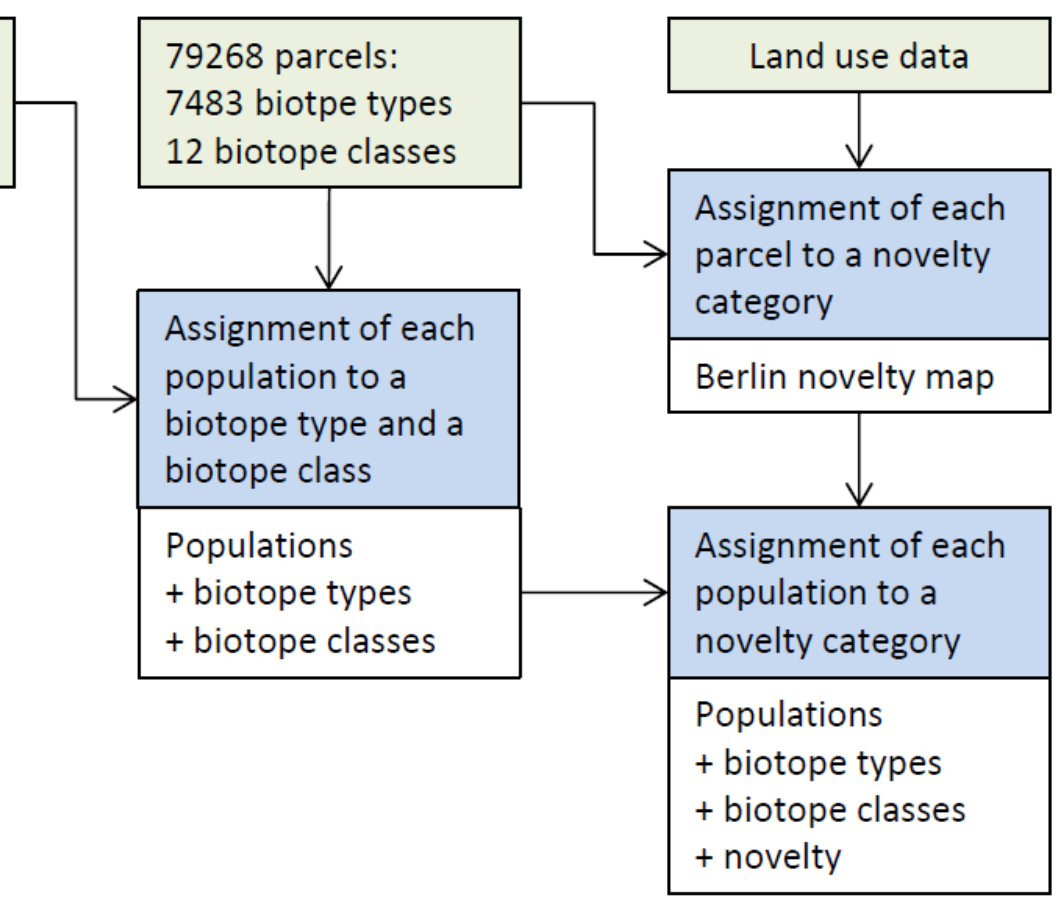

\section{ECOLOGICAL NOVELTY}

